\title{
Intercropping of castor bean and sugarcane under irrigation: part 2: yield and agronomic indices
}

\author{
Francisco Figueiredo de Alexandria Júnior, Everton John Camelo Alves*, \\ Silvanete Severino da Silva, José Dantas Neto, Carlos Alberto Vieira de Azevedo
}

Federal University of Campina Grande, Campina Grande, Brazil

*Corresponding author, e-mail: everton.ufcg@hotmail.com

\begin{abstract}
Intercropping can be an alternative to maximize yields of castor bean and sugarcane. This work aimed to investigate the yields and agronomic indices of castor bean and sugarcane in intercropping system. The experiment was carried out in the field, at the Ponta da Serra Farm, in the municipality of Queimadas-PB, Brazil. Treatments resulted from a $4 \times 4$ factorial arrangement, with twelve replicates. The irrigation depths (drip system) tested were: 50, 75, 100 and 125\% crop evapotranspiration, and the spacings used for castor bean were: $(1 \times 0.5 \mathrm{~m}),(1 \times 1 \mathrm{~m}),(1 \times 1.5 \mathrm{~m})$ and $(1 \times 2 \mathrm{~m})$, that is, $20,000,10,000,6,666$ and 5,000 plants per hectare, respectively, with total area of $2,880 \mathrm{~m}^{2}$, each one with twelve plots of castor bean spacing. The following variables were evaluated: land equivalent ratio and relative crowding coefficient. For all irrigation depths tested, sugarcane yield increased linearly with the increment in castor bean spacing. The highest value of land equivalent ratio was found at $1 \times 0.5 \mathrm{~m}$ spacing, and the lowest values of relative crowding coefficient for sugarcane occurred at $1 \times 0.5 \mathrm{~m}$ spacing for all irrigation depths.
\end{abstract}

Keywords: 'BRS energia', Ricinus communis L., yield, evapotranspiration

\section{Introduction}

Castor bean (Ricinus communis L.) is an oilseed crop with high socioeconomic value and its seeds contain high contents of oil with potential for biodiesel production. Its cultivation encompasses various regions, but the main producers are India, China and Brazil, reaching yield levels of up to $95 \%$ (Almeida et al., 2007; Ribeiro et al., 2009FAOSTAT, 2011 ; Souza-Schlick, 2012; Diniz Neto et al., 2012).

Due to the edaphoclimatic conditions of Northeast Brazil, castor bean is recommended for biodiesel production, because it is adapted to the climate and has high potential to generate jobs and keep local workers in rural areas, reducing rural flight (Lima et al., 2014).

Sugarcane, valued for its capacity to generate clean, renewable energy, is currently based on the use of hydrocarbon fuels of fossil origin (Farias et al., 2009). Nonetheless, agroindustrial yield of sugarcane depends upon rainfalls along its entire cycle (Silva et al., 2015) and/or irrigation.

To improve biological yield, Pinto \& Pinto (2012) claim that intercrops are very common in Northeast Brazil and aim to enhance the efficiency of production factors. This production system ensures greater stability in the production, reducing the risks associated with the characteristic adverse climate of the semi-arid region, guaranteeing the generation of income 
for small farmers.

The performance of the intercropping system can be investigated by measuring yield, land equivalent ratio (LER) and relative crowding coefficient (K) (BEZERRA NETO et at., 2007).

Yield is the total mass of plants per area unit. This mass can be expressed in quantity of seeds and is possibly influenced by spacing because the smaller the spacing between plants, the larger their population. On the other hand, Zuchi et al. (2010) state that the lower the water availability and the later the sowing of the crop, the lower the yield, and consequently the production.

LER is the land area under sole cropping required to adjust the increase of intercropped yields, i.e., a comparative analysis between intercropping and sole cropping (MEAD, WILLEY, 1980). When the agro-system efficiency (AEI) is assessed based on land equivalent ratio, if the AEI (agro-system efficiency index) is higher than 1, the intercropped system is advantageous and leads to "over-yielding"; otherwise, there is no advantage and it leads to "under-yielding" (TEIXEIRA et al., 2005). On the other hand, $K$ is one of the agronomic indices most related to the interspecific competitions established in the intercropped agro-system.

Given the above, this study aimed to investigate the yields and agronomic indices of castor bean and sugarcane in intercropping system.

\section{Material and Methods}

The experiment was conducted in the field in an area belonging to the Ponta da Serra Farm, in the municipality of QueimadasPB, Agreste Paraibano region, at geographic coordinates $7^{\circ} 22^{\prime} 00^{\prime \prime} \mathrm{S}$ and $36^{\circ} 00^{\prime} 06^{\prime \prime} \mathrm{W}$, at mean altitude of $482 \mathrm{~m}$. The climate is hot and humid, with mean rainfall of $600 \mathrm{~mm}$, temperature between $24^{\circ} \mathrm{C}$ (minimum) and $30^{\circ} \mathrm{C}$ (maximum), with relative air humidity of $65 \%$.

The soil in the experimental area is eutrophic, with medium texture, sandy loam (SL) (Table 1).

Table 2 shows soil chemical analysis, which was sent to the Laboratory of Irrigation and Salinity (LIS) of the Center of Technology and Natural Resources (CTRN) of the Federal University of Campina Grande (UFCG).

The experiment used the castor bean cultivar 'BRS Energia', which is considered as early, with average cycle of 120 days and short, $1.40 \mathrm{~m}$ tall. The other species used was sugarcane, SP 791011 variety, at spacing of $1.00 \mathrm{~m}$ between rows. Castor bean spacing was established within each plot after the first cut of sugarcane.

Treatments resulted from the combination of four irrigation depths: 50, 75, 100 and $125 \%$ crop evapotranspiration, with four spacings of castor bean, corresponding to (1 $\mathrm{x}$ $0.5 \mathrm{~m}),(1 \times 1 \mathrm{~m}),(1 \times 1.5 \mathrm{~m})$ and $(1 \times 2 \mathrm{~m})$, which represented 20,000, 10,000, 6,666 and 5,000 plants per hectare, concomitantly. The total area of the experiment was $2,880 \mathrm{~m}^{2}$, divided into four irrigation sectors, each one with twelve plots of castor bean spacing.

The experiment also had a neighboring area with treatments of castor bean and sugarcane in sole cropping; for each irrigation depth, there was one plot of castor bean at $1 \times 1 \mathrm{~m}$ spacing and one plot of sugarcane in sole cropping (no intercropping). The design was randomized blocks with split plots, and irrigation depths were arranged in strips whereas castor bean spacings corresponded to the subplots. Each experimental plot had 6 rows of sugarcane with $10 \mathrm{~m}$ in length, spaced by $1 \mathrm{~m}$ and interspersed with castor bean, totaling $60 \mathrm{~m}^{2}$. Data were collected in the 4 central rows of each plot, in a segment of 8 linear meters (disregarding $1 \mathrm{~m}$ on each end), totaling $32 \mathrm{~m}^{2}$.

Chemical characterization of irrigation water was carried out at LIS/CTRN/UFCG. Table 3 shows the results of the water quality analysis. In a qualitative analysis, the water was classified as C4, with very high risk of salinization, and cannot be used for irrigation under normal conditions. Soils must be permeable, with adequate drainage, and water must be applied in abundance to allow good leaching of salts and, in spite of that, they need to be cultivated with crops highly tolerant to salts.

The water used for irrigation came from the Bodocongó stream, belonging to the Paraíba River Basin. Outlet pressure in the pump was kept at 54 m.w.c. and pumped by a 7-hp 
Table 1. Physical-hydraulic analysis of the soil in the experimental area, Queimadas, PB, Brazil.

\begin{tabular}{|c|c|c|}
\hline $\begin{array}{l}\text { Soil physical char } \\
\text { Granulometry }\end{array}$ & stics & Value \\
\hline Granulometry (g.kg-1) & $\begin{array}{c}\text { Sand } \\
\text { Silt } \\
\text { Clay }\end{array}$ & $\begin{array}{c}64.24 \\
30.67 \\
5.09\end{array}$ \\
\hline \multicolumn{2}{|l|}{ Textural class } & Sandy loam \\
\hline Density $\left(\mathrm{g} / \mathrm{cm}^{3}\right)$ & $\begin{array}{c}\text { Bulk } \\
\text { Particle }\end{array}$ & $\begin{array}{l}2.83 \\
1.52\end{array}$ \\
\hline \multicolumn{2}{|l|}{ Total porosity (\%) } & 46.29 \\
\hline \multicolumn{2}{|l|}{ Field capacity (\%) (-0.33 atm) } & 4.37 \\
\hline \multicolumn{2}{|c|}{ Permanent wilting point (\%) (-15 atm) } & 2.92 \\
\hline \multicolumn{2}{|l|}{ Available water (\%) } & 1.45 \\
\hline
\end{tabular}

Table 2. Chemical analysis of the soil in the experimental area, Queimadas, PB, Brazil.

\begin{tabular}{ll}
\hline Soil chemical characteristics & Value \\
\hline Calcium (meq/100g of soil) & 3.22 \\
Magnesium (meq/100g of soil) & 3.39 \\
Sodium (meq/100g of soil) & 0.15 \\
Potassium (meq/100g of soil) & 0.60 \\
Sum of bases (meq/100g of soil) & 7.36 \\
Hydrogen (meq/100g of soil) & 0.66 \\
Aluminum (meq/100g of soil) & 0.00 \\
CEC (meq/100g of soil) & 8.02 \\
Calcium Carbonate (Qualitative) & Absence \\
Organic Carbon (g.kg-1) & 0.86 \\
Organic Matter (g.kg-1) & 1.48 \\
Nitrogen (\%) & 0.08 \\
Assimilable Phosphorus (mg/100g) & 2.10 \\
PH $\mathrm{H}_{2} \mathrm{O}(1: 2.5)$ & 5.65 \\
EC (mmhos/cm) & 0.21 \\
\hline
\end{tabular}

Table 3. Chemical analysis of the irrigation water used in the experimental area, Queimadas, PB, Brazil.

\begin{tabular}{lc}
\hline \multicolumn{1}{c}{ Chemical characteristics of the water } & Value \\
\hline $\mathrm{pH}$ & 6.75 \\
Electrical conductivity $\left(\mu \mathrm{S} \mathrm{m} \mathrm{m}^{-1}\right)$ & 2.26 \\
Calcium (meq L-1) & 3.27 \\
Magnesium $\left(\mathrm{meq} \mathrm{L}^{-1}\right)$ & 5.29 \\
Sodium (meq L-1) & 11.94 \\
Potassium (meq L-1) & 0.51 \\
Chlorides (meq L-1) & 0.00 \\
Sulfates (meq L-1) & 5.38 \\
Bicarbonates $\left(\mathrm{meq} \mathrm{L}^{-1}\right)$ & 14.47 \\
Carbonates $\left(\mathrm{meq} \mathrm{L}^{-1}\right)$ & Absence \\
Sodium adsorption ratio - SAR (mmol L-1) & 5.77 \\
Class & $\mathrm{C} 4$ \\
\hline
\end{tabular}

motor pump set, passing through a 600-m-long 75-mm-diameter PVC main line, until reaching the control head, where it was filtered by a 130-micron disc filter, with flow rate of $10 \mathrm{~m}^{3} \mathrm{~h}^{-1}$. After each screen filter, an analog manometer was installed to control pressure. Secondary piping had nominal diameter of $50 \mathrm{~mm}$ and length of $60 \mathrm{~m}$, with lines for each water depth, totaling five units connected to the main pipe by quick-release ball valves, which regulated the entry of water to supply the lateral lines, in each strip of irrigation. The irrigation system was a perforated-tube localized drip system, with mean flow rate of 8 L.h $^{-1}$ at each hole. Lateral lines were made of polyethylene with nominal diameter of $16 \mathrm{~mm}$, arranged in each plant row, i.e., a distance of $1.0 \mathrm{~m}$ between lateral lines was adopted. 
In regard to irrigation application, in the second year of experiment, castor bean was planted with the same criteria used for sugarcane in the previous year, i.e., first cycle of the crop. Irrigation depths were determined based on evapotranspiration (ETo), to estimate ETc. Reference evapotranspiration (ETo) was determined every day, using the Penmann \& Monteith model, according to the methodology proposed by Cavalcante Junior et al. (2011), which is the most adequate for the region:
The first irrigation was carried out using the same level in all sectors, so that all treatments were at field capacity at the beginning of the study. Only then water depth treatments began to be applied, with irrigations every seven days. Crop evapotranspiration was calculated as follows: ETC = ETO. KC. Crop coefficients $(\mathrm{KC})$ recommended by Doorenbos \& Kassam (1994) were used for the different growth stages, to determine crop evapotranspiration in each one of them (Table 4).

Table 4. Crop coefficients (KC) for sugarcane at different growth stages. Doorenbos \& Kassam, 1994.

\begin{tabular}{lcc}
\hline \multicolumn{1}{c}{ Ground cover (\%) } & Period duration (days) & Kc \\
\hline \multirow{2}{*}{0 to 0.25} & $0-30$ & 0.40 \\
& $30-45$ & 0.50 \\
& $45-60$ & 0.60 \\
\hline \multirow{2}{*}{0.25 to 0.50} & $60-80$ & 0.75 \\
& $80-100$ & 0.85 \\
\hline 0.50 to 0.75 & $100-125$ & 0.95 \\
\hline 0.75 to 100 & $125-180$ & 1.10 \\
\hline \multirow{2}{*}{ Maximum demand } & $180-270$ & 1.20 \\
\cline { 2 - 3 } & $270-300$ & 1.30 \\
\hline Early senescence & $300-330$ & 1.00 \\
Maturation & $330-360$ & 0.60 \\
\hline
\end{tabular}

Water levels in the form of volume (measured in liters) were calculated by multiplying the ETc of each growth stage of sugarcane by $0.5,0.75,1.0$ and 1.25 , to obtain the water depths L1, L2, L3 and L4 ( $\mathrm{mm}$ day $^{-1}$ or 1.0 L. $^{-2}$ day $\left.^{-1}\right)$, corresponding to the replacement of 50,75 , 100 and $125 \%$ crop evapotranspiration. Then, the values of the water depths L1, L2, L3 and L4 were multiplied by the area of 12 plots (Splot $=60 \mathrm{~m}^{2}$ ), which corresponded to each water depth, obtaining the volume required to meet the daily levels of water replacement presented previously. Since dripper flow rate was 8 L.h-1 and the volume in $L$ necessary to meet the irrigation depths tested was known, the required volume was divided by dripper flow rate to obtain the operation time of the system.

Table 5 presents the irrigation depths applied along the year of cultivation and the respective effective rainfalls. Effective rainfall for the treatments was different and increased according to the water depth tested.

Table 5. Irrigation depth, rainfall, effective rainfall and total water depth applied in the crop, Queimadas, PB, Brazil.

\begin{tabular}{lccc}
\hline \multicolumn{1}{c}{ Treatment } & Rainfall & Irrigation depth & Total water depth \\
\hline $50 \%$ ETC & & 360.00 & 730.00 \\
$75 \%$ ETC & \multirow{2}{*}{616.66} & 540.00 & 823.66 \\
$100 \%$ ETC & & 720.00 & 948.16 \\
$125 \%$ ETC & 900.00 & 1060.33 \\
\hline
\end{tabular}

Cultivation practices were carried out along the experiment. Basal fertilization consisted of $90 \mathrm{Kg} \mathrm{ha}^{-1}$ of $\mathrm{N}, 80 \mathrm{~kg} \mathrm{ha}^{-1}$ of $\mathrm{P}_{2} \mathrm{O}_{5}$ and $60 \mathrm{Kg} \mathrm{ha}^{-1}$ of $\mathrm{K}_{2} \mathrm{O}$, using urea $(46 \% \mathrm{~N})$, single superphosphate $\left(22 \% \mathrm{P}_{2} \mathrm{O}_{5}\right)$ and potassium chloride $\left(60 \% \mathrm{~K}_{2} \mathrm{O}\right)$ as sources of nutrients. Weeding was carried out at 60-day intervals after castor bean was planted.

Based on soil chemical analysis, treatments, experimental design, chemical characterization of irrigation water and its quality analysis, definition of agricultural equipment, irrigation in the second year and the cultivation practices (fertilization and weeding), all performed before the analysis of growth of castor bean intercropped with sugarcane, treatment effects were evaluated based on the 
production of seeds and stalks in each plot. The data obtained in the plots were transformed to $\mathrm{kg}$. $\mathrm{ha}^{-1}$ and used to calculate the agronomic indices, namely: land equivalent ratio (LER) and relative crowding coefficient (K).

LER was calculated according to following formula, Willey (1979):

$$
L E R=\left(\frac{Y_{a b}}{Y_{a a}}+\frac{Y_{a b}}{Y_{b b}}\right)
$$

Where:

Yab: yield of castor bean intercropped with sugarcane;

Yaa: yield of castor bean in sole cropping;

Yba: yield of sugarcane intercropped with castor bean;

Ybb: yield of sugarcane in sole cropping.

The coefficient $K$ was calculated by the following formula:

$$
K a b=\left(\frac{Y_{a b} \cdot Z_{b a}}{\left(\left(Y_{a a} \cdot Y_{a b}\right) \cdot Z_{a b}\right)}\right)
$$

Where:

Kab: effect of castor bean intercropped with sugarcane;

Yab: yield of castor bean intercropped with sugarcane;

Zba: sown proportion of sugarcane in mixture with castor bean;

Yaa: yield of castor bean in sole cropping;

Zab: sown proportion of castor bean in mixture with sugarcane.

The effect of sugarcane intercropped with castor bean, $\mathrm{Kba}$, is estimated likewise.

The values of agronomic indices were subjected to simple analysis of variance, $\mathrm{F}$ test, Tukey test ( 0.01 and 0.05 probability levels) and regression analysis, according to Ferreira (2008).

\section{Results and discussion}

Table 6 presents the summary of analysis of variance for the yields of castor bean and sugarcane.

Castor bean yield decreased linearly with the reduction in its own population (see Figure 1).

Table 6. Summary of analysis of variance (mean squares) and mean values for castor bean yield $\left(\mathrm{Kg} \mathrm{ha}^{-1}\right)$ and

\begin{tabular}{|c|c|c|c|}
\hline Source of variation & DF & Castor bean ( $\left.\mathrm{kg} \mathrm{ha}^{-1}\right)$ & Sugarcane (ton $\mathrm{ha}^{-1}$ ) \\
\hline Blocks & 11 & & \\
\hline Irrigation depth (L) & 3 & $71848.07^{\mathrm{ns}}$ & $1017.2^{\mathrm{ns}}$ \\
\hline Residual a & 33 & 52365.25 & 235.24 \\
\hline Spacing (S) & 3 & $25087.46^{* *}$ & $97.29^{* *}$ \\
\hline$L \times S$ & & $34580.27^{n s}$ & $350.75^{\mathrm{ns}}$ \\
\hline Residual b & 55 & 14330.33 & 527.55 \\
\hline $\mathrm{CV}(\%)$ & & 14.21 & 25.52 \\
\hline
\end{tabular}
sugarcane yield (ton $\mathrm{ha}^{-1}$ ).

$1^{* *}$ significant at 0.01 probability level $(p<0.01),{ }^{*}$ significant at 0.05 probability level $(0.01 \leq p<0.05)$, ns not significant $(p \geq 0.05)$

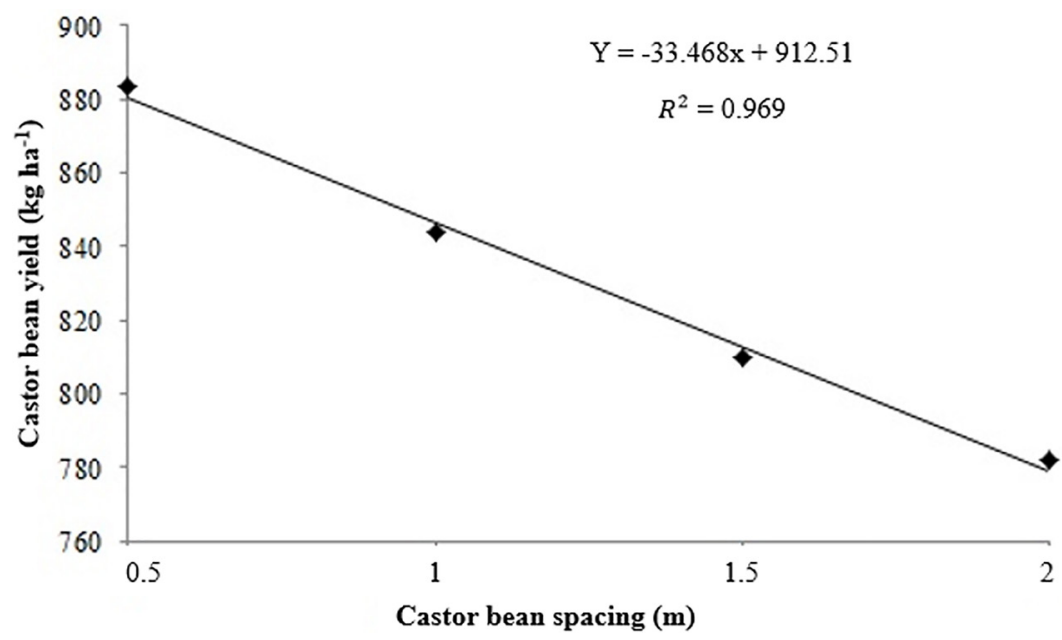

Figure 1. Regression of castor bean yield as a function of its spacing. Queimadas, PB, Brazil.

Thus, it is possible to state that the optimal population of this crop will be higher than 20,000 plants ha $^{-1}$. Highest castor bean yields, 885.26,
840.16 and $804.25 \mathrm{~kg} \mathrm{ha}^{-1}$ (Table 7), were found at the smallest spacings, i.e., where there was a higher number of plants. Plants subjected to 
increasing population densities tend to exhibit increased yield, due to the presence of higher number of plants per area unit. It is evident that such increase will only be observed up to the optimal population, beyond which yield will decrease.

Sugarcane yield increased linearly with the increment in castor bean spacing (Figure 2).

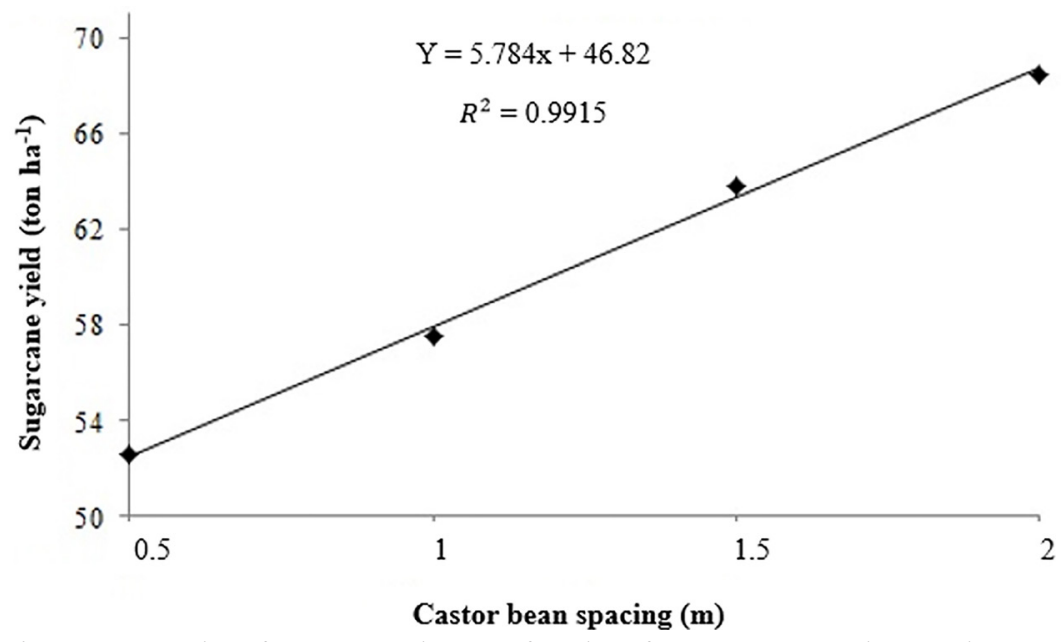

Figure 2. Regression of sugarcane yield as a function of castor bean spacing. Queimadas, $\mathrm{PB}$, Brazil.

As the number of castor bean plants decreased, sugarcane yield increased, which is due to the interspecific competition between the species for light, nutrients and water. This can be attributed to its lower competitiveness compared to castor bean, and such effect is related to the higher production potential of this crop, since this plant occupies a more favorable position in the system. Regarding light interception, higher yield for this species was also due to its greater ability to compete with the other species in the intercropping system.

The photosynthetic metabolism of C3 plants with photosynthetic rate between 18 and $27 \mathrm{mg} \mathrm{CO}_{2} \mathrm{dm}^{-2} \mathrm{~h}^{-1}$ need at least 2,900 degreedays of heat until reaching maturity. On the other hand, plants which produce sugars, such as sucrose of sugarcane, and with C4 metabolism, in the production of energy, for instance, spend only $1 / 3$ to produce oil (BELTRÃO \& OLIVEIRA, 2008).

In regard to the agronomic indices presented in Table 6, differences between treatments were found at irrigation depth of $50 \%$ ETc. All intercropped systems had LER higher than one. When the agroecosystem efficiency was assessed based on the use of LER, the results indicated that the treatment of sugarcane + castor bean at spacing of $1 \times 0.5 \mathrm{~m}$ would be $33 \%$ more efficient than castor bean in sole cropping.
The intercropping system will be efficient when AEl is higher than 1.0 and harmful to production when it is lower than 1.0; any value higher than 1.0 indicates yield advantage of the intercropped system, a result referred to as "over-yielding". The other treatments of sugarcane + castor bean did not differ statistically from one another and from the treatment of sugarcane + castor bean at spacing of $1 \times 0.5 \mathrm{~m}$.

For the relative crowding coefficient, the highest value for castor bean was found in the treatment of sugarcane + castor bean (1x1m), in which castor bean produced 3.72 times more than expected, differing from the relative crowding coefficient of sugarcane, in which the same treatment led to the lowest yields. The expected yield would be the one obtained if each species were subjected to the same degree of competition, both in mixture and in sole cropping, i.e., if the interspecific competition were equal to the intraspecific competition (Table 7).

Regarding the agronomic indices presented in Table 7, differences between treatments were found at irrigation depth corresponding to $75 \%$ ETC. All intercropped systems had LER higher than one. When the agroecosystem efficiency was assessed based on LER, the results indicated that the treatment of sugarcane + castor bean at spacing of $1 \times 0.5$ 
$m$ would be $64 \%$ more efficient than the sole cropping of castor bean. The other treatments of sugarcane + castor bean did not differ from one another and from the treatment of sugarcane + castor bean at spacing of $1 \times 0.5 \mathrm{~m}$.

Table 7. Comparisons between treatment means considering the land equivalent ratio (LER) and the relative crowding coefficients for castor bean $(\mathrm{Kcb})$ and sugarcane $(\mathrm{KsC})$ at irrigation depth corresponding to $50 \%$ ETC, Queimadas, PB, Brazil.

\begin{tabular}{lccc}
\hline \multicolumn{1}{c}{ Treatments } & \multicolumn{3}{c}{ Variables } \\
\cline { 2 - 4 } & LER & Kcb & K \\
\hline Sugarcane in sole cropping & 1 & -- & -- \\
Castor bean in sole cropping & 1 & - & - \\
Sugarcane + Castor bean $(1 \times 0.5 \mathrm{~m})$ & $1.33 \mathrm{a}$ & $2.64 \mathrm{ab}$ & $0.92 \mathrm{a}$ \\
Sugarcane + Castor bean $(1 \times 1 \mathrm{~m})$ & $1.17 \mathrm{~b}$ & $3.72 \mathrm{a}$ & $1.67 \mathrm{a}$ \\
Sugarcane + Castor bean $(1 \times 1.5 \mathrm{~m})$ & $1.21 \mathrm{~b}$ & $1.35 \mathrm{ab}$ & $2.61 \mathrm{a}$ \\
Sugarcane + Castor bean $(1 \times 2 \mathrm{~m})$ & $1.22 \mathrm{~b}$ & $1.15 \mathrm{~b}$ & $1.54 \mathrm{a}$ \\
\hline Overall Mean & 1.23 & 2.22 & 1.68 \\
\hline CV (\%) & 2.94 & 3.77 & 8.33 \\
\hline Obs.: For LER, statistical analysis was carried out only with intercropped treatments. Means followed by the same letter in the column do not differ by Tukey test \\
at 0.05 probability level.
\end{tabular}

For the relative crowding coefficient, the highest value for castor bean was found in the treatment of sugarcane + castor bean (1×2m), in which castor bean produced 4.47 times more than expected, differing from the relative crowding coefficient of sugarcane, in which the same treatment led to the lowest yields (Table 8).

Table 8. Comparisons between treatment means considering the land equivalent ratio (LER) and relative crowding coefficient for castor bean (Kcb) and sugarcane $(\mathrm{KsC})$ at irrigation depth corresponding to $75 \%$ ETc. Queimadas, $\mathrm{PB}$, Brazil.

\begin{tabular}{lccc}
\hline \multirow{1}{*}{\multicolumn{1}{c}{ Treatments }} & \multicolumn{3}{c}{ Variables } \\
\cline { 2 - 4 } & LER & Kcb & Ksc \\
\hline Sugarcane in sole cropping & 1 & -- & -- \\
Castor bean in sole cropping & 1 & - & -- \\
Sugarcane + Castor bean $(1 \times 0.5 \mathrm{~m})$ & $1.64 \mathrm{a}$ & $4.16 \mathrm{a}$ & $0.73 \mathrm{a}$ \\
Sugarcane + Castor bean $(1 \times 1 \mathrm{~m})$ & $1.22 \mathrm{~b}$ & $3.81 \mathrm{a}$ & $2.35 \mathrm{a}$ \\
Sugarcane + Castor bean $(1 \times 1.5 \mathrm{~m})$ & $1.13 \mathrm{~b}$ & $0.99 \mathrm{~b}$ & $2.45 \mathrm{a}$ \\
Sugarcane + Castor bean $(1 \times 2 \mathrm{~m})$ & $1.59 \mathrm{a}$ & $4.47 \mathrm{a}$ & $1.38 \mathrm{a}$ \\
\hline Overall Mean & 1.39 & 3.35 & 1.73 \\
\hline CV (\%) & 5.35 & 15.71 & 3.58 \\
\hline
\end{tabular}

According to Table 8, all intercropped systems had LER higher than one. When the agroecosystem efficiency was assessed based on LER, the results indicated that the treatment of sugarcane + castor bean at spacing of $1 \times 0.5 \mathrm{~m}$ would be $56 \%$ more efficient than castor bean in sole cropping. The other treatments of sugarcane + castor bean did not differ statistically from one another and from the treatment of sugarcane + castor bean at spacing of $1 \times 0.5 \mathrm{~m}$.

For the relative crowding coefficient, the highest value for castor bean was found in the treatment of sugarcane + castor bean $(1 \times 1.5$ $\mathrm{m})$, in which castor bean produced 3.74 times more than expected, almost double the relative crowding coefficient of sugarcane, in which the same treatment led to the lowest yields (Table 9).

In regard to the agronomic indices presented in Table 9, differences between treatments were found at irrigation depth corresponding to $100 \%$ ETC. All intercropped treatments had LER higher than one. When the agroecosystem efficiency was assessed based on LER, the results indicated that the treatment of sugarcane + castor bean at spacing of $1 \times 0.5$ $m$ would be $70 \%$ more efficient than castor bean in sole cropping. The other treatments of sugarcane + castor bean differed statistically from one another and from the treatment of sugarcane + castor bean at spacing of $1 \times 0.5 \mathrm{~m}$. 
For the relative crowding coefficient, the highest value for castor bean was found in the treatment of sugarcane + castor bean $(1 \times 0.5 \mathrm{~m})$, in which castor bean produced 2.81 times more than expected, similar to the relative crowding coefficient of sugarcane, in which the same treatment led to the lowest yields (Table 10).

Table 9. Comparisons between treatment means considering the land equivalent ratio (LER) and relative crowding coefficients for castor bean (Kcb) and sugarcane (KsC) at irrigation depth corresponding to $100 \%$ ETc. Queimadas, PB, Brazil.

\begin{tabular}{lccc}
\hline \multirow{2}{*}{ Treatments } & \multicolumn{3}{c}{ Variables } \\
\cline { 2 - 4 } & LER & Kcb & K \\
\hline Sugarcane in sole cropping & 1 & -- & -- \\
Castor bean in sole cropping & 1 & -- & - \\
Sugarcane + Castor bean $(1 \times 0.5 \mathrm{~m})$ & $1.56 \mathrm{a}$ & $2.81 \mathrm{ab}$ & $0.93 \mathrm{a}$ \\
Sugarcane + Castor bean $(1 \times 1 \mathrm{~m})$ & $1.19 \mathrm{~b}$ & $3.59 \mathrm{a}$ & $2.46 \mathrm{~b}$ \\
Sugarcane + Castor bean $(1 \times 1.5 \mathrm{~m})$ & $1.30 \mathrm{~b}$ & $3.74 \mathrm{a}$ & $2.04 \mathrm{~b}$ \\
Sugarcane + Castor bean $(1 \times 2 \mathrm{~m})$ & $1.19 \mathrm{~b}$ & $1.26 \mathrm{~b}$ & $2.31 \mathrm{~b}$ \\
\hline Overall Mean & 1.31 & 2.85 & 1.93 \\
\hline CV (\%) & 3.04 & 23.98 & 34.54 \\
\hline
\end{tabular}

Table 10. Comparisons between treatment means considering the land equivalent ratio (LER) and relative crowding coefficients for castor bean $(\mathrm{KCb})$ and sugarcane $(\mathrm{KsC})$ at irrigation depth corresponding to $125 \%$ ETc. Queimadas, PB, Brazil.

\begin{tabular}{lccc}
\hline \multirow{2}{*}{ Treatments } & \multicolumn{3}{c}{ Variables } \\
\cline { 2 - 4 } & LER & Kcb & K \\
\hline Sugarcane in sole cropping & 1 & -- & -- \\
Castor bean in sole cropping & 1 & - & -- \\
Sugarcane + Castor bean $(1 \times 0.5 \mathrm{~m})$ & $1.70 \mathrm{a}$ & $2.81 \mathrm{a}$ & $0.99 \mathrm{a}$ \\
Sugarcane + Castor bean $(1 \times 1 \mathrm{~m})$ & $1.52 \mathrm{~b}$ & $2.59 \mathrm{a}$ & $1.68 \mathrm{a}$ \\
Sugarcane + Castor bean $(1 \times 1.5 \mathrm{~m})$ & $1.23 \mathrm{c}$ & $2.79 \mathrm{a}$ & $2.41 \mathrm{a}$ \\
Sugarcane + Castor bean $(1 \times 2 \mathrm{~m})$ & $1.42 \mathrm{~b}$ & $2.00 \mathrm{a}$ & $2.11 \mathrm{a}$ \\
\hline Overall Mean & 1.47 & 1.73 & 1.79 \\
\hline CV (\%) & 3.80 & 8.35 & 5.01 \\
\hline
\end{tabular}

\section{Conclusions}

Castor bean yield was significantly influenced by the spacings tested, and the spacing of $1 \times 0.5 \mathrm{~m}$ led to the highest yield. Sugarcane yield was influenced by castor bean population and its maximum value occurred at the smallest spacing of castor bean.

The highest land equivalent ratio was more significant for spacing than for the irrigation depths applied, and the lowest values of relative crowding coefficient (K) for sugarcane were obtained at $1 \times 0.5 \mathrm{~m}$ spacing for all irrigation depths studied.

\section{References}

Almeida, A. P.; Guerra, H. O. C.; Barros Júnior, G.; Cavalcanti, M. L. F.; Lacerda, R. D. Desenvolvimento e produção da variedade de mamona BRS-188 sob diferentes níveis e fontes de macronutrientes. Revista Pesquisa 1:27-35.
Ribeiro, S.; Chaves, L. H. G.; Guerra, H. O. C.; Gheyi, H. R.; Lacerda, R. D. de. Resposta da mamoneira cultivar BRS-188 Paraguaçu à aplicação de nitrogênio, fósforo e potássio. Revista Ciência Agronômica 40: 465-473.

Beltrão, N. E. de M.; Oliveira, M. I. P. de. Diferenciação na produção de energia entre oleaginosas (metabolismo C3) e energéticas (C4). Embrapa Algodão (Campina Grande, PB). 2008.

Bezerra Neto, A. P. A.; Pitombeira, J. B.; Távora, F. J. A. F.; Vidal Neto, F. C. 2007. Rendimento, componentes da produção e uso eficiente da terra nos consórcios sorgo $x$ feijão de corda e sorgo x milho. Revista Ciência Agronômica 38: 104-108.

Cavalcante Júnior, E.G.; Oliveira, A.D.; Almeida, B.M. de; Espínola Sobrinho, J. 2011. Métodos de estimativa da evapotranspiração de referência para as condições do semiárido Nordestino. Semina: Ciências Agrárias 32: 1699-1708.

Diniz Neto, M. A.; Silva, I. F. da; Diniz, B. L. M. T.; 
Pereira, A. de A.; Pereira, A. R. 2012. Componentes de produção de mamona em função de níveis de adubação nitrogenada e desfolha. Revista Ciência Agronômica 43: 546-553.

Doorenbos, J.; Kassam, A. H. Efeito da água no rendimento das culturas. Campina Grande: UFPB, 306 p. (FAO. Estudos de Irrigação e Drenagem, 33), 1994.

FAOSTAT (2011) Production - Castor Oil Seeds, 2009. United Nations Food and Agriculture Organization. http://faostat.fao.org/site/567/ DesktopDefault.aspx?PagelD=567. <Acesso em: 6 Abr. 2016>

Farias, C, H. de A.; Fernandes, P. D.; Gheyi, H. R.; Dantas Neto, J. 2009. Qualidade industrial de cana-de-açúcar sob irrigação e adubação com zinco, em Tabuleiro Costeiro paraibano. Revista Brasileira de Engenharia Agrícola e Ambiental 13: 419-428.

Ferreira, D. F. 2008. Sisvar: Sistema de análise de variância versão 4.6. UFLA/DEX, Lavras, Brasil.

Lima. G. S. de; Nobre, R. G.; Gheyi, H. R.; Soares, L. A. dos A.; Lourenço, G. da S.; Silva, S. S. da. 2014. Aspectos de crescimento e produção da mamoneira irrigada com águas salinas e adubação hidrogenada. Revista Brasileira de Engenharia Agrícola e Ambiental 18: 615-622.

MEAD, R.; WILLEY, R. W. The concept of a land equivalent ratio and advantages in yields for intercropping. Experimental Agriculture, v. 16, p. 217-228, 1980.

Pinto, C. de M.; Pinto, O. R. de O. 2012. Avaliação da eficiência biológica e habilidade competitiva nos sistemas de consorciação de plantas. Enciclopédia Biosfera, Centro Científico Conhecer 8: 105-122.

Silva, S.; Dantas Neto, J.; Teodoro, I.; Silva, S. S. da; Nascimento, R.; Barbosa, G. V. de S. 2015. Economic depth of drip irrigation on sugarcane. Irriga, Botucatu, Edição Especial, IRRIGA \& INOVAGRI: 37-46.

Souza-Schlick, G. D. de; Soratto, R. P.; Bottino, D.; Fernandes, A. M. 2012. Crescimento e produtividade da mamona de porte baixo em diferentes espaçamentos e populações de plantas. Interciência 37: 49-54.

Teixeira, I. R.; Mota, J. H.; Silva, A. G. da. 2005. Consórcio de hortaliças. Semina: Ciências Agrárias. Semina: Ciências Agrárias 26: 507-51 4.

Zuchi, J.; Zanuncio, J. C.; Bevilaqua, G. A. P.; Peske, S.T.; Silva, S. D. dos A. e. 2010. Componentes do rendimento de mamona segundo a ordem floral e época de semeadura no Rio Grande do Sul. Revista Ciência Agronômica 41: 380-386.
Willey, R. W. Intercropping: its importance and research needs: Part 1. Competition Intercropping: its importance and research needs: Part 1. Competition and yield advantages.1979. Field Crops Abstracts 32: 1-10. 